\title{
Economic Valuation of Mangrove Restoration in Indonesia
}

Djoko Suprapto', Mayanggita Kirana ${ }^{2}$, Indah Susilowati ${ }^{2}$, Akhmad Fauzi $^{3}$

${ }^{1}$ Faculty of Fisheries and Marine Science, Diponegoro University

${ }^{2}$ Faculty of Economics and Business, Diponegoro University

Jalan Prof H. Soedarto, S.H., Tembalang, Semarang, Indonesia.

${ }^{3}$ Department of Resource Economics, Bogor Agricultural University

Jalan Kamper Kampus IPB Dramaga Gd. Fakultas Ekonomi dan Manajemen W5L5

Dramaga Bogor, Indonesia. Correspondence e-mail: kiranamayanggita@gmail.com

Received: July 2015; Accepted: October 2015

\begin{abstract}
Mangrove forest is one of the important ecosystems in Karimunjawa, Indonesia. It provides a variety of services both ecologically and economically. However, over-exploited activity, such as timber theft, can be threatening the sustainability of mangrove forest in Karimunjawa now and in the future. Thus, the improved management for mangrove forest is necessary to ensure its sustainability, and it is depending on how people value the conservation from economic and environment consideration. This study examines the factors influencing on the willingness to pay (WTP) of respondents for mangrove restoration in Karimunjawa. A total of 502 respondents were interviewed using census method. The method employed is Contingent Valuation Method (CVM) Single Bounded. In CVM, the logit model was defined based on dichotomous choice method to estimate the willingness-to-pay (WTP) randomly with three different starting bid value. Findings showed that local awareness of the importance of the values given by mangroves was popularized among local communities. The findings also indicated that respondents who are higher education and have more income were more likely to pay for the mangrove restoration.
\end{abstract}

Keywords: economic-valuation, mangrove, Karimunjawa, Indonesia

JEL Classification: Q51, Q57

\section{Penilaian Ekonomi dalam Pemulihan Hutan Bakau Di Indonesia}

\begin{abstract}
Abstrak
Hutan bakau adalah salah satu ekosistem penting di Karimunjawa, Indonesia. Hutan ini menyediakan berbagai layanan ekologis dan ekonomis, tetapi kegiatan eksploitasi yang berlebihan, seperti pencurian kayu, dapat mengancam keberlanjutan hutan bakau di Karimunjawa saat ini dan juga di masa depan. Dengan demikian, peningkatan manajemen hutan bakau diperlukan untuk memastikan keberlanjutannya, dan itu tergantung pada bagaimana orang memberikan nilai pada konservasi dari pertimbangan ekonomi dan lingkungan. Studi ini mempelajari faktor-faktor yang mempengaruhi pada kemauan untuk membayar (WTP) responden untuk restorasi hutan bakau di Karimunjawa. Total 502 responden yang diwawancarai menggunakan metode sensus. Metode yang digunakan adalah Contingent Valuation Method (CVM) Single Bounded. Di CVM, model logit didefinisikan berdasarkan metode pilihan dichotomous untuk memperkirakan WTP secara acak dengan tiga nilai tawaran awal yang berbeda. Temuan menunjukkan bahwa kesadaran lokal tentang pentingnya nilai-nilai yang diberikan terhadap hutan bakau dipopulerkan di masyarakat setempat. Temuan lain juga mengindikasikan bahwa responden yang berpendidikan tinggi dan berpenghasilan lebih banyak, lebih suka membayar kegiatan restorasi hutan bakau.
\end{abstract}

Kata kunci: penilaian ekonomis, hutan bakau, Karimunjawa, Indonesia

Klasifikasi JEL: Q51, Q57 


\section{Jurnal Ekonomi Pembangunan, 16 (2), Desember 2015, 121-130}

\section{Introduction}

The great potency of Indonesia's territorial waters and richness of the Indo-West Pacific seas further add to the country's biodiversity. It supports a rich variety of coastal and marine habitats. Karimunjawa is $6^{\text {th }}$ largest of Indonesia's marine national park (Campbell, et. al., 2012). There are several types of ecosystem in Karimunjawa National Park, such as coral reef, sea grass and seaweed, mangrove, coastal forest, and tropical rain forest (BTNKJ, 2014). Nowadays, the actual condition of mangrove forest in Karimunjawa is not known well, though the community has taken advantage of certain types of mangrove to fulfill their needs. Moreover, over-exploited activity which can be threatening mangrove forest starts to be revealed, such as timber theft. Given these threats, improved management is necessary to ensure the sustainability of mangroves resources in Karimunjawa now and in the future. The success of mangrove conservation management will be depending on how people value the conservation from economic and environment consideration.

Mangrove ecosystem offers a huge number of goods such as food, fuel wood, timber, honey, wax, and tannins. For the ecological importance, it is widely recognized for being an effective sediment trapping, shorelines protection from erosion, nutrient cycling, and being a natural habitat for fish and crustacean. Besides, mangrove ecosystem also has aesthetic, cultural, and historical value (FAO, 2007). Due to these multi-advantages, it causes mangrove ecosystem as well as the one of important resources in the coastal area.

In general ways, mangrove ecosystem is threatened by the increasing consumption pressure as the impact of the population explosion, unsustainable production of fish and prawns, and mixing of waste water effluents from urbanindustrialization area and oil-spill (Datta, et. al., 2012). Even though some studies had been conducted to estimate the extent of mangrove in worldwide, the different technic and methodology used in the research subjected to different results of the extent of mangrove ecosystem. Furthermore, due to uncertain boundary of mangrove ecosystem, it is also difficult to have an actual report related to the extent of mangrove ecosystem, whether it were in a good or damaged condition. Though mangrove ecosystem in Indonesia has been declining drastically in recent years, nevertheless, Indonesia stands for the country with the largest mangrove ecosystem in Asia, and worldwide.

The rehabilitation of the damaged mangrove ecosystem can be done by restoration efforts. Restoration is defined as an effort to recover the degraded forest area to the original condition or close to it (Whitten, et. al., 2000). But it needs to be emphasized that community involvement may be a key factor in intensifying the potential for successful mangrove restoration (Ellison, 2000). The logical reasons for this argument are (a) more often agencies have limited budget to implement their planned restoration effort and manage it. They can leverage their small budget from the community contributions of cash, labor, physical resources and management input, (b) any restoration effort against the community's wish may result in a potential backlash and a unsuccessful program (Stone, et. al., 2008).

The value of mangrove restoration is an irreversible loss, which should be conserved as it brings a sense of belonging. There are many competing and important projects that will need government funding. Therefore, the qualification of government projects in monetary terms allows policy makers to prioritize conservation programs and projects with limited and tight budgets. Proper conservation guidelines and implementation could halt further irreversible loss of mangrove restoration so that present and future generations would be able to enjoy and experience them first-hand.

The community willingness to be involved to the mangrove ecosystem restoration effort is widely measured using economic valuation approach by Contingent Valuation Method (CVM). CVM is a survey-based method which goods are traded in a constructed or hypothetical market. This method was originally proposed by Ciriacy and Wantrup (1974), and was implemented by Davis (1963) and Armirnejad, et. al., (2006), and is being the most frequently used stated preference technique for estimating non-market values. CVM is called contingent 


\section{Jurnal Ekonomi Pembangunan, 16 (2), Desember 2015, 121-130}

because respondents were asked to state their willingness-to-pay (WTP) contingent upon the environment or other hypothetical market built (Chea, 2013). Thus, the approach used to determine individual's willingness for the payment of the environment usage and utilization.

The comprehension due to this concept, however, allows the policy makers to manage and to utilize a wide range of natural resources and environment at the most effective and efficient level, and enable to distribute the conservation benefit and cost in a conscionable way. Referring to the description of the background, to estimate the communities' willingness to be involved in mangrove ecosystem restoration through willingness to pay (WTP), further studies are needed to be carried out. The objectives of this researches to estimate the community participation towards the restoration of mangrove forest in Kemujan Island - Karimunjawa. Kemujan Island is the second-largest island (1,500 ha), which is adjacent to Karimunjawa Island and has the only airport in the group (Dewadaru Airport). Karimunjawa and Kemujan are connected by approximately $350 \mathrm{~m}$ of mangrove forest and a bridge, so it appears to be one single island (Susanto, 2014).

\section{Research Method}

The concept of economic valuation has attracted important attention in many studies related to coastal development (Tuan, et. al., 2014; Stone, et. al., 2008; Wegner and Pascual, 2001; and Hammit, et. al., 2001). It is claimed that the concept can be easily applied and obviously redeem the damaged coastal area. According to Choi et.al. (2009), the interest of valuation is estimating the total economic value, which includes not only use values but also intangible non-use values which were not normally captured in the private market transactions. Total economic value can be estimated using stated preference non-market valuation techniques. When reliable market data are not available, researchers may need to create a hypothetical market to elicit consumers' preferences. Stated preference (SP) techniques were used on the event that required WTP information that cannot be obtained from the markets. It is relevant to case of conserving mangrove ecosystem because there is no market exists (Bateman and Turner, 2002). Majority of conservation studies used the CVM because of its ability to measure both the use and non-use values of resources and elicit the monetary value of a change in a public good and services. The type, credibility and acceptability of the payment mechanism described in the survey questionnaire can affect the WTP values.

CVM is a survey-based approach that involves developing a hypothetical market, by directly asking to an individual to state his or her willingness to pay (WTP) for the environmental service conserved in a particular location and/or willingness to accept (WTA) as the compensation for any damages (Mitchell and Carson, 1989; Pearce and Turner, 1990). In this research, CVM was used for valuing mangrove ecosystem restoration, and it aims to assess the willingness to pay of communities for the restoration of mangrove ecosystem. CVM is generally divided into six stages: (1) setting the hypothetical market; (2) obtaining bids; (3) estimating mean WTP; (4) estimating bid curves; (5) aggregating the data; (6) evaluating the CVM exercise (Hanley and Spash, 1993; Vo et.al, 2012; Tuan et.al, 2014). Setting the hypothetical market for the improvement of the asset sets up the reason for payment but the payment is not actually collected. The survey instrument where the fee payment is determined, what type of project is it, and how funds are collected is described at this stage. Bid (the maximum WTP for the improvement project) can be gathered using dichotomous choice (DC). Single bounded DC-CVM involved in determining a range of bidding price, while each respondents was asked just a single bid that indicates his or her maximum WTP value for that particular good (Abdullah, 2015). In this method, the respondents are only asked to state their "yes" or "no" response to the offered bid amount. The initial bids are varied among individuals in order to gather more information about the true WTP distribution (Venkatachalam, 2003).

The decision whether the respondents willing to pay the restoration charge or not is based on the assumption that when people faced with a possible set of discrete choices, they will 


\section{Jurnal Ekonomi Pembangunan, 16 (2), Desember 2015, 121-130}

select the alternative that maximizes their utility. Hence, this model, assumes that an individual is willing to pay the bid amount (B) only if they gain value by enhancing the conservation and maintenance is generating utility, which is equal or greater than their utility when no charge is made and the ecosystem is maintained at the current or lower levels. This can be express as follows:

$\mathrm{U}(1, \mathrm{Y}-\mathrm{B} ; \mathrm{S})>\mathrm{U}(0, \mathrm{Y} ; \mathrm{S})$

where $x=0$ refers to the acceptance of current level for mangrove conservation in Karimunjawa National Park and $x=1$ is the condition of improved levels for the mangrove ecosystem restoration; $Y$ is the income, $\mathrm{B}$ is the offer, and $\mathrm{S}$ is other socio-economic characteristics affecting preference, that may affect the WTP decision.

The utility function can be algebraically defined as the sum of its non-stochastic and stochastic components:

$\mathrm{U}(\mathrm{x}, \mathrm{Y} ; \mathrm{S})=\mathrm{V}(\mathrm{x}, \mathrm{Y} ; \mathrm{S})+\varepsilon \mathrm{x}$,

where $x=0,1$

$\mathrm{U}(1, \mathrm{Y}-\mathrm{B} ; \mathrm{S})+\varepsilon_{1} \geq \mathrm{U}(0, \mathrm{Y} ; \mathrm{S})+\varepsilon_{0}$

where $\varepsilon_{0}$ and $\varepsilon_{1}$ are the identically, independently distributed random variables with zero means. The utility difference $(\Delta U)$ could be measured using:

$\Delta \mathrm{U}=\mathrm{U}(1, \mathrm{Y}-\mathrm{B} ; \mathrm{S})-\mathrm{U}(0, \mathrm{Y} ; \mathrm{S})+\left(\varepsilon_{1}-\varepsilon_{0}\right)$

An approximation of utility difference can be used for the empirical analysis:

$\Delta \mathrm{U}=\mathrm{a}+\mathrm{BB}+\mathrm{Y} \mathrm{Y}+\theta \mathrm{S}$

Therefore, the more a respondent pays (the amount money of $\mathrm{B}$ is more), the lesser utility they will obtain. The maximum WTP represents the situation that monetary value is so high.
The utility that the respondents received from the usage of the mangrove ecosystem are assumed lesser than the charge amount. Therefore, the utility gained from the mangrove ecosystem would be equal to the situation when no charges. It can be shown as:

WTP $\max =\left[\mathrm{U}(1, \mathrm{Y}-\mathrm{B} ; \mathrm{S})+\varepsilon_{1}=\mathrm{U}(0, \mathrm{Y} ; \mathrm{S})+\varepsilon_{0}\right]$

An additional consideration specified by economic theory is that maximum WTP is bounded by their ability to pay. Income is supposed to be upper bound on WTP. Assumption is that the respondents know which choice will maximize their utility, this choice is not clear to the researcher because of unobservable component which make the utility function more complicated. Therefore, the respondent' response can be expressed in a probabilistic framework. Thus, individual's choice is considered as a random variable that the probability of its distribution is given by:

$\mathrm{Py}=\mathrm{P}(\mathrm{WTP})=\mathrm{P}\left[\mathrm{U}(1, \mathrm{Y}-\mathrm{B} ; \mathrm{S})+\varepsilon_{1}\right]$

$\mathrm{Pn}=\mathrm{P}$ (willingness not to pay) $=1-\mathrm{Py}$

The difference in the error terms represented by $\eta=\varepsilon_{1}-\varepsilon_{0}$ and $F \eta$ (.) corresponds to the cumulative density function (cdf) of $\eta$. Thus, the probability of WTP can be written as:

$\operatorname{Py}=\operatorname{Fn}(\Delta \mathrm{U})$

The term Fn $(\Delta U)$ is a random variable, which implies the cumulative probability distribution function of the respondent's maximum WTP. In the logit model, Fn (.) is cdf of a standard, logistic variant. It can be further expressed as:

$\operatorname{Py}=\operatorname{Fn}(\Delta U)=1 / 1+\exp (\Delta U)$

$\mathrm{Py}=1 / 1+\exp \left(-\left[\mathrm{aBB}+\mathrm{y}_{\mathrm{Y}}+\theta \mathrm{S}\right]\right)$ 


\section{Jurnal Ekonomi Pembangunan, 16 (2), Desember 2015, 121-130}

when $B \leq 0 ; \mathrm{Y}>0$; and $\theta>0$

An alternative way to demonstrate the binary response probabilities in eq (7) can be expressed as:

$\mathrm{Py}=\mathrm{P}(\mathrm{WTPmax}>\mathrm{B})$

$\mathrm{Py}=1-\mathrm{GWTP} \max (\mathrm{B})=\mathrm{Fn}(\Delta \mathrm{U}(\mathrm{B}))$

The GWTP $\max ($.$) refers to the cdf of$ WTPmax. The term Fn $(\Delta \mathrm{U}(\mathrm{B}))$ denotes that the $\mathrm{P}(\mathrm{WTPmax}>\mathrm{B})$ is a function of the differences in the distribution in the error term (Fn). This can be redefined as a function of changes in the observable components of utility $(\Delta U)$. Accordingly, the observable components of the utility function are $\mathrm{x}, \mathrm{Y}$, and $\mathrm{S}$. The term $(\Delta U)$ is affected by (B) affects (Y) which is an argument of the utility function $\mathrm{U}(\mathrm{x}, \mathrm{Y}, \mathrm{S})$.

Bishop and Heberlein (1979), applied a particular form of the logit function to analyze data from CVM. WTP is random and non-negative variable, the mean WTP is:

WTPmax $=$ Expected value of WTPmax

$\mathrm{E}(\mathrm{WTPmax})=\int_{0}^{\infty}[1-\operatorname{GWTPmax}(\mathrm{B})] \mathrm{dB} ;$

where $\lim \mathrm{B} \rightarrow 0$ GWTPmax $(\mathrm{B})=0$ and $\lim$ $\mathrm{B} \rightarrow+\infty$ GWTPmax $(\mathrm{B})=1$

The eq 12) guarantees the conditions that the area below the probability distribution function is equal to one and it implies that the mean WTP is equal to the expected value of maximum WTP, which is indicated by $\mathrm{E}$.

The responses (Y) of the dichotomous choice WTP generally are regressed against a constant bid amount (BID), along with the vector of different socioeconomic variables (X) using logistic function

$\mathrm{Y}=\frac{1}{1+\mathrm{e}^{-\left(\alpha+\beta_{1} \mathrm{X}_{1}+\beta_{2} \mathrm{X}_{2}+\cdots+\beta_{\mathrm{k}} \mathrm{X}_{\mathrm{k}}\right)}}$
The logistic function estimates the probability of accepting the offered bid by household for restoration of mangrove, which is a function of bid amount and set of respondent's socioeconomic characteristic. The variable, $Y$ is supposed to be binomial, taking the value of 1 for a "yes" and 0 for "no" response. In order to estimate this function, the probability of "yes" responses can be modeled for different bid amount and socioeconomic variables (such as income, education, age, etc). A variation of linear in bid model which is to use the log of bidding amount and consistent with a utility difference formulation and can be used in the procedure, refer to eq 13). The transformation of BID to log value has the advantages of restricting the mean between zero and infinity, whereas the linearin-bid model is not comprised with this rule (Giraud et.al, 2001)

$\mathrm{Y}=\mathrm{F} \eta(\Delta \mathrm{U})=\frac{1}{1+\mathrm{e}^{-\left(\alpha+\beta_{1} \mathrm{X}_{1}+\beta_{2} \mathrm{X}_{2}+\cdots+\beta_{\mathrm{k}} \mathrm{x}_{\mathrm{k}}\right)}}$

With the assumption WTP is a non-negative random variable the mean WTP can be written:

$\mathrm{E}(\mathrm{WTP})=\int_{0}^{\operatorname{MaxB}} \mathrm{F \eta}(\Delta \mathrm{U}) \mathrm{dB}$

$\mathrm{E}(\mathrm{WTP})=\int_{0}^{\operatorname{MaxB}} 1 /\left(1+\exp \left\{\alpha^{*}+\beta \mathrm{B}\right\} \mathrm{dB}\right.$

Where E(WTP) is the expected value of WTP, and $a^{*}$ is the adjusted intercept which was added by the socioeconomic term to the original intercept term of $\alpha,\left[\alpha^{*}=(\alpha+\gamma Y+\varrho S)\right]$. The error term is small when there are large differences in systematic utility between alternatives one and two. Large errors are likely when differences in utility are small, thus decision makers are more likely to choose an alternative on the "wrong" side of the indifference line.

This research was located in Mangrove Zone, Kemujan Island because it has relatively good mangrove forest for ecotourism development. A total 502 respondents was collected based on the total households with 95\% confi- 


\section{Jurnal Ekonomi Pembangunan, 16 (2), Desember 2015, 121-130}

dence level and approximately 4.4\% margin of error. These respondents were randomly picked in various type of jobs in Karimunjawa. Several socioeconomic characteristic was used in this study are income, education level, marital status, number of family, and age. Selected variable based on the implications from economic theory and the findings of previous study (Chea, 2013; Yacob, 2008; Throsby, 2003).

Table 1. Variables' Measurement

\begin{tabular}{llc}
\hline Variable & \multicolumn{1}{c}{ Description } & $\begin{array}{c}\text { Expected } \\
\text { Sign }\end{array}$ \\
\hline Income & $\begin{array}{l}\text { Respondent's income } \\
\text { per annum }\end{array}$ & $(+)$ \\
$\begin{array}{l}\text { Education } \\
\text { level }\end{array}$ & $\begin{array}{l}\text { The level of } \\
\text { education level }\end{array}$ & $(+)$ \\
Marital & $\begin{array}{l}1=\text { married, } \\
0=\text { otherwise }\end{array}$ & $+/-$ \\
Number & $\begin{array}{l}\text { Amount of family } \\
\text { member }\end{array}$ & $+/-$ \\
Age family & $\begin{array}{l}\text { Respondent's age } \\
\text { (years) }\end{array}$ & $+/-$ \\
Sex & $\begin{array}{l}1=\text { male } \\
0=\text { female } \\
\text { Bid amount offered }\end{array}$ & $+/-$ \\
\hline
\end{tabular}

Note: dependent variable is WTP ( $1=\mathrm{yes} ; 0=\mathrm{no})$

\section{Results and Discussion}

The respondents' age is between 18 years old to 72 years old, with mean of 25 years old. There are $44.1 \%$ of the respondents are male. Classification of the respondents based on the education level shows that $10.3 \%$ of them completed their diploma, $35.7 \%$ with the secondary school, and $54 \%$ of them had primary school certificate. As for the marital status, 53\% of them are currently married, $47 \%$ of them are married and widowed. Meanwhile, from the occupation of view, $97.8 \%$ are currently on full time employment in fisheries sector and 2.2\% are not working due to the health problems.

From society's point of view, the net returns per rai from mangroves should include total economic value. This study, however, includes only some of the use values which consist of both direct and indirect use values. The economic value of mangrove based on this study (which includes only direct use value by local communities and indirect use value in terms of off-shore fishery linkages and the value in terms of coastline protection) is Rp.6.700.000,00 per rai. In the real case, under an open access situation, NPV is highest at Rp.75.000.000,00 per rai when the discount rate is $6 \%$ and the elasticity of demand is -0.1 . The higher the elasticity of demand, the larger the transfer from consumers to producers, resulting in a higher net welfare gain. Therefore, given the same discount rate and other things being equal, NPV will be larger as the elasticity of demand increases.

Table 2. The Estimated Economic Value

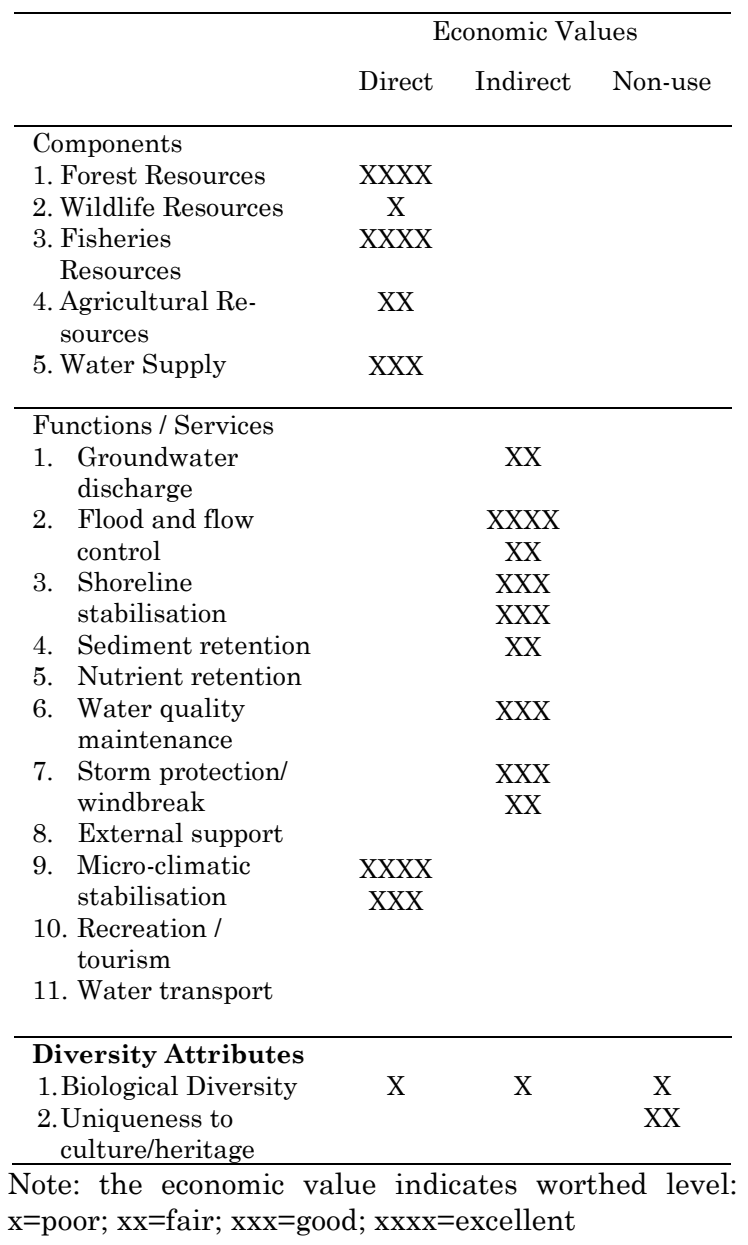

CVM applied in this study is used to estimate WTP of the respondents towards man- 


\section{Jurnal Ekonomi Pembangunan, 16 (2), Desember 2015, 121-130}

grove ecosystem restoration efforts in Karimunjawa. All of the respondents were provided information describing the existing condition of damaged and degraded mangrove ecosystem in Karimunjawa. Respondents are also given explanation about the restoration planning of mangrove ecosystem which aims to conserve mangrove ecosystem mangrove through planting, seeding, maintaining, and silvo fishery. Community involvement may be a key factor in intensifying the potential for successful mangrove restoration so it needs participation from communities. The amount of contribution is based on the hypothetical scenario through indepth interview with some key persons in the related departments. There were 3 bids offered


and $\operatorname{Rp} 24,000.00$.

Investigations in answers to WTP indicated that $43 \%$ respondents $(n=213)$ agree to contribute to the restoration mangrove ecosystem in Karimunjawa. A bivariate logit model is used to estimate the regression equation. The results obtained are consistent with several past studies; Becker et al (1998) had significant WTP with marital status of the respondents, Sakonnakon et. al. (2012) had significant WTP with the respondents' income and level of education. Bidding price, income, level of education, and marital status are important factors that affect WTP.

Table 3. Final Logit Model

\begin{tabular}{|c|c|c|c|}
\hline \multirow[t]{2}{*}{ Variable } & \multicolumn{2}{|c|}{ Model (overall) } & \multirow{2}{*}{$\begin{array}{l}\text { Odd- } \\
\text { ratio }\end{array}$} \\
\hline & B & S.E & \\
\hline Bid & -0.240516 & $\begin{array}{l}0.070430 * \\
* *\end{array}$ & - \\
\hline Education & 1.023701 & $0.556045^{*}$ & 2.783478 \\
\hline Marital & 0.555707 & $\begin{array}{l}0.208802^{*} \\
* *\end{array}$ & 1.743174 \\
\hline Family & 0.320632 & 0.348948 & 1.377998 \\
\hline Age & -0.324482 & 0.224069 & 0.722902 \\
\hline Sex & 0.106745 & 0.208394 & 1.112651 \\
\hline Income & 0.000046 & $\begin{array}{l}0.000007^{*} \\
* *\end{array}$ & - \\
\hline Constant & -0.816822 & $\begin{array}{l}0.391545^{*} \\
*\end{array}$ & 0.441833 \\
\hline
\end{tabular}

-2 Log likelihood $=578.816583$

Nagelkerke R Square $=0.254817$

Cox \& Snell R Square $=0.189630$

$\mathrm{N}=502$
Note: dependent variable is WTP $(1=$ yes; $0=$ no $)$

For the final model, the bid amount variable is significantly different from zero (at $1 \%$ level of significance for the overall model). As expected, the sign is negative, which means this variable had highly significant and negative effect on the probability of a respondent saying "yes" to contribute to mangrove' restoration charge to Karimunjawa National Park.

Household income is an important factor that can influence respondent' WTP and significant at $1 \%$ for the final model. As expected, the sign is positive, indicates that as income increases, WTP increases as well. The marital status is another important factor that has effect on respondent's WTP for the final model, statistically significant at $1 \%$ for the final model with an expected positive sign. The positive sign suggests that married respondents have higher WTP. Other than that, education level is also significant at $10 \%$ with a positive sign, indicates that educated respondent have higher WTP in the mangrove restoration. Most of them are low educated respondent and need some education program regarding to ecology aspect and level of satisfaction. Normally, higher educated people have a better gross monthly income and demand more information and knowledge about the conservation and managing ecology. They might assume they would get a better experience from their participation.

The results of socioeconomic indicator has some potential implications and these information is very useful, not only for management and planning purposes but also in particular for the marketing strategies. Majority respondents' age is between 20 and 30 years old. The information suggests government should have effective plan that could concentrate on a particular age range, such as certain activities that are suitable for this ages group that could maximize the utilization of their limited resources. The WTP analysis is a simple vehicle to elicit the demand for the benefits of better ecosystem that people received. It should be mentioned that to underdo survey in determining the value of willingness to pay from people in developing country like in the study area is not easy. This might due to many people are more concern to give more value in spending their basic needs 


\section{Jurnal Ekonomi Pembangunan, 16 (2), Desember 2015, 121-130}

rather than appreciation in the value of openaccess resource such as Karimunjawa Island.

The mean WTP of respondents denoted $\mathrm{E}(\mathrm{WTP})=\int_{0}^{\infty} 1-\mathrm{F}(\mathrm{z} ;$. $) \mathrm{dz}$, where $\mathrm{F}(\mathrm{z} ;$.$) is the cdf$ which gives the probability of observing a particular value of WTP or less. However, the data collected shows that $42 \%$ of the respondents still answer "yes". The mean WTP can be calculated as the area under the step function according to $E(W T P)=\sum_{j=3}^{7} S(B J)\left[\widehat{B J}-B_{J}-q\right]=\mathrm{Rp} 17.500,00$. Meanwhile, the value of standard deviation for this study is Rp22.900,00.

Nagelkerke $\mathrm{R}^{2}$ and Cox\&Snell $\mathrm{R}^{2}$ provide a logistic analogy to $\mathrm{R}^{2}$ in OLS regression. TheNagelkerke measures range from 0 to 1 and its measure adapts the Cox\&Snell $\mathrm{R}^{2}$. In this study, Nagelkerke $R^{2}$ 0.255153. Another indication of regression model fit is given by 2loglikelihood or -2LL value. The probability of the observed regression result, given the parameter estimates is known as the likelihood. It is customary to use -2times the natural log likelihood. -2likelihood or -2LL as a measured model of fit because it has ties to the chi square distribution. A good model that has log likelihood translates to a small value for -2LL. For a perfect fit, -2LL must be zero. In this case, the $2 \mathrm{LL}$ values is 578.662020 . This implies that the variables employed in the model (e.g.: bid, education, marital, family etc.) is able to explain the willingness to pay (WTP) of respondents accordingly.

\section{Conclusions}

Many of such environmental goods are subjected to the well known "market failure". One of the primary objectives of non-market valuation is increasing public awareness about this value and contributing to better-informed public decisions. Environmental valuation studies could endeavor where everyone's voice is heard through the benefits and costs of the gain, regardless of how much a person contributed. Valuation studies have to potential to provide an effective way to diminish the often-bemoaned role of special interest in the current policy process.

The benefit of restorating mangrove ecosystem for the society based on WTP can help pol- icy makers understand the consequences for present policies on the values in the long run. The results showed that $43 \%$ agreed to pay or contribute to the hypothetical restoration charge. The demographic variables are important predictors of WTP. Income, education level, marital status, and bidding value were significant predictors in single bounded CVM. This study can provide the policy makers an indicator on the conservation value that household willing to pay and support for the restoration programs.

This study provides additional insight to designing ideal starting bid range value and WTP estimates. Natural resource including mangrove ecosystem is an important part of wealth in the country. If the increase in aggregate benefits exceeds the increase in aggregate costs, conservation would be interpreted as worthwhile from the society's perspective. Policy makers should allocate the resource more efficiently in conserving mangrove ecosystem given that the benefits are substantial with limited budget. It is realized that the management of mangrove in the study area is still far from complete although many efforts has been put on by the academician (A), Business (B), Government (G), and Community (C). Hence, in the future indeed need to have a better co-management among the stakeholders (A-B-G-C) to secure the valuable resource of mangrove in Karimunjawa.

Acknowledgement. We would like to express our gratitude to the Directorate of Research and Social Service, Higher Degree of Education (DRPM-Dikti) - Ministry of Research, Technology and Higher Degree Education (Menristek \& Dikti), Indonesia for providing a research funding. This paper benefited for the useful comments from anonymous reviewers. Thanks to our students for helping us in data collection.

\section{References}

Abdullah, Mukrimah, Mohd Parid Mamat, Mohd Rusli Yaacob, Alias Radam, Lim Hin Fui. 2015. Estimate the conservation value of biodiversity in national heritage site: a case of forest research institute. 


\section{Jurnal Ekonomi Pembangunan, 16 (2), Desember 2015, 121-130}

Procedia Environmental Sciences. Vol 30, (180-185)

Amirnejad, H Khalilian, S, Assarch, M, H, Ahmadian, M. 2006. Estimating the existence value of north forest of Iran by using a Contingent Valuation Method. Ecological Economics. 58 (4) 665-675.

Bateman I. and R. Turner. 2002. Evaluation of environment: the contingent valuation method, CSERGE Working Paper GEC 92-18.

Becker, N. Choresh Y, Inbar M, Bahat.O. 1998. Combining $\mathrm{TCm}$ and $\mathrm{CVM}$ of endangered species conservation programme: Estimation of the Marginal Value of Vultures in the presence of species visitors interaction, Biodiversity Economics, 313-342.

Bishop RC and Heberlein. 1989. The Contingent Valuation Method in economic valuation of natural resources. Land Economics 68(4): 405-417.

BTNKJ. 2014. Laporan Tahunan Balai Taman Nasional Karimunjawa 2013. Kementerian Kehutanan, Direktorat Jenderal Perlindungan Hutan dan Konservasi Alam.

Campbell, S. J., Hoey A. S., Maynard J., Kartawijaya T., and Cinner J. 2012. Weak compliance undermines the success of no-take zones in a large government Controlled MPA. PLoS ONE Vol. 7 (11): e50074. doi:10.1371/journl.pone.0050074.

Chea, Chiam Chooi. 2013. The Benefits of Conserving Living Heritage in Melaka City, Melaka. Dissertation. Economic Faculty of University Putra Malaysia.

Choi, A, Brent W. Ritchie, Franco Papandera, Jeff Bennett. 2009. Economic valuation of cultural heritage: a choice modeling approach. Elsevier.

Ciriacy, Wantrup, C.V., 1968. Resource Conservation: Economics and Policies. University of California, Berkeley.

Datta, Debajit, Chattopadhyay, R.N., Guha, P. 2012. Community Based Mangrove Man- agement: a Review on Status and Sustainability. Journal of Environmental Management. Vol. 107,84-95.

Davis, R. 1963. Recreation planning as an economic problem. Natural Resources Journal, 3 (2), 239-249.

Ellison, A.M. 2000. Mangrove Restoration: Do We Know Enough? Restoration Ecology 8(3):219-29.

Food Agriculture Organization (FAO). 2007. The World's Mangroves 1980e2005: A Thematic Study Prepared in the Framework of the Global Forest Resources Assessment 2005. FAO Forestry Paper 153, Food and Agriculture Organization of the united nations, Roma, Italy.

Giraud, K.L., Loomis, J.B., and Cooper, J.C. 2001. A Comparison of Willingness to Pay Estimation Techniques from Referendum Questions. Environmental and Resource Economics 20: 331-346.

Hammitt, James, Jin-Tan Liu, and Jin-Long Liu. 2001. Contingent Valuation of A Taiwanese Wetland. Environment and Development Economics Journal. Vol. 6, pp. 259-268.

Hanley, N. and Spash C.L. 1993. Cost-Benefit Analysis and the Environment, Edward Elgar Publishing Limited';'+

Mitchell R.C, Carson R.T. 1989. Using surveys to value public goods: the contingent valuation method. Resources for the future. Washington DC.

Pearce D.W and Turner R.K. 1990. Economics of Natural Resources and The Environment. The John Hopkins University Press, Baltimore, pp.378.

Sakonnakon S.PN, Hirunsalee S, Kanegae H, Denpaiboon C. 2012. Valuing externalities from water supply: choice complexity and individual random effect in panel kernel logit analysis. Journal of Environmental Planning and Management, 50(4): 449456. 
Jurnal Ekonomi Pembangunan, 16 (2), Desember 2015, 121-130

Stone, Kathy, Mahadev Bhat Ramachandra Bhatta and Andrew Mathews. 2008. Factors Influencing Community Participation in Mangrove Restoration: A Contingent Valuation Analysis. Ocean and Coastal Management, Vol. 51, pp. 476-484.

Susanto, Hary, Imam Taufiquraarhman, and S. Van Balen. 2014. Waders of Karimunjawa National Park, Central Java, Indonesia. Stilt. Vol. 66, Page 1-9.

Throsby, D. 2003. Determining the Value of Cultural Goods: How Much does Contingent Valuation Tell Us? Journal of Cultural Economics Vol. 27(3): 275-285.

Tuan, Tran Huu, Nguyen Hoang Diem Mym Le Thi Quinh Anh, dan Nguyen Van Toan. 2014. Factors Influencing Community Participation in Mangrove Restoration: A Contingent Valuation Analysis. Ocean and Coastal Management Journal, Vol. 95, pp. 198-212.

Venkatachalam, L. 2003. Designing Contingent Valuation (CV) Surveys for Estimating
Use Values: Some Experience from Case Study of a Water Supply Project. Journal of Social and Economic Development, Vol. 5 (2): 267-284.

Vo,Quoc Tuan, C.Kuenzer, Quang Minh Vo, F. Moder, N. Oppelt. 2012. Review of valuation methods for mangrove ecosystem services. Ecological Indicators Vol 23, 431446.

Wegner, G., Pascual, U., 2011. Cost-benefit analysis of ecosystem services for human well-being: A multidisciplinary critique. Global Environmental Change 21 (2), 492-504,

Whitten, T., R.E. Soeriaatmadja, and S.A. Afiff. 2000. The Ecology of Java and Bali. Singapore: Periplus.

Yacob, M.R, Radam A., and Shuib A. 2008. Economic valuation of Marine Parks Ecotourism Malaysia: Redang Island Marine Park. University Putra Malaysia Press.

\section{Appendix}

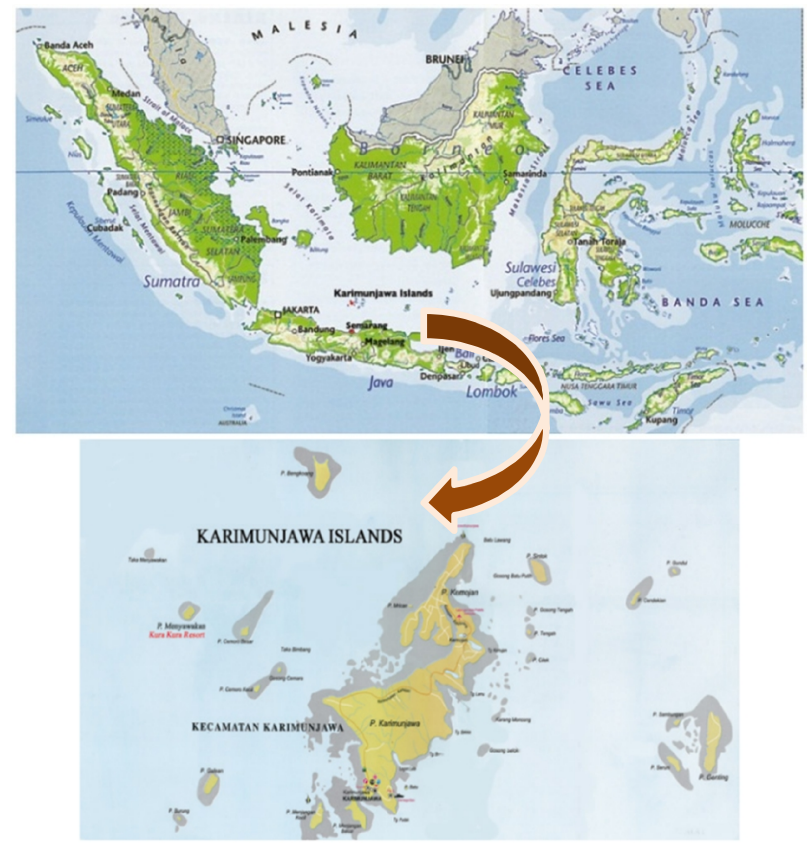

Figure 1. Map of Study Area

Source: Statistic of Karimunjawa, BTNKJ (2014) 